\title{
Plant homeostasis of foliar manganese sinks: specific variation in
}

\section{hyperaccumulators}

Authors in order of appearance on manuscript:

Denise R Fernando ${ }^{1}$

Ian E Woodrow ${ }^{2}$

Alan J M Baker ${ }^{2}$

Alan T Marshall ${ }^{3}$

Institution addresses:

1 The Department of Botany, La Trobe University, Melbourne, Victoria 3086, Australia.

2 School of Botany, The University of Melbourne, Victoria 3010, Australia.

3 Analytical Electron Microscopy Laboratory, Faculty of Science and Technology \& Engineering, La Trobe University, Melbourne VIC 3086, Australia.

Corresponding author's details:

Dr Denise Rita Fernando

Department of Botany

La Trobe University

Bundoora, Victoria 3086

AUSTRALIA

$\mathrm{P}+61394793567 \quad \mathrm{~F}+61394791188 \quad \mathrm{E}$ d.fernando@latrobe.edu.au 


\begin{abstract}
Plant manganese (Mn) hyperaccumulation provides unusual insight into homeostasis of this essential micronutrient, in particular its excessive storage in shoot tissues. The compartmentation of hyperaccumulated foliar Mn appears exceptional among metal hyperaccumulators, since it occurs via specific microdistribution patterns. Here, three associated Mn hyperaccumulators, Virotia neurophylla, Maytenus fournieri, and Garcinia amplexicaulis exhibiting distinctly different $\mathrm{Mn}$ detoxification strategies were examined. Non invasive sample preparation in conjunction with cryo scanning electron microscopy (SEM) was used to obtain in vivo quantitative microprobe X-ray and anatomical data from fully hydrated cells. Highly vacuolated large palisade mesophyll cells in V. neurophylla leaves were found to contain around $650 \mathrm{mM} \mathrm{Mn}$. The large non-photosynthetic hypodermal cells of $M$. fournieri leaves, also with high vacuolar content, and the main site for $\mathrm{Mn}$ disposal, had an estimated mean vacuolar Mn concentration of around $600 \mathrm{mM}$. Previous qualitative X-ray mapping had shown Mn to be almost evenly sequestered across the entire leaf cross section of G. amplexicaulis. However, quantitative data obtained here showed a marked variation in localised concentrations that ranged between $\sim 15 \mathrm{mM}$ and $>800 \mathrm{mM}$. Notable among these were mean values of $>600 \mathrm{mM}$ in spongy mesophyll cells, and $\sim 800$ $\mathrm{mM}$ within cells of a narrow sub epidermal layer preceding the palisade mesophyll. This study demonstrated the extraordinary Mn carrying capacities of different types of leaf cell vacuoles.
\end{abstract}

\title{
Keywords
}

Manganese hyperaccumulator, foliar Mn sequestration, Virotia neurophylla, Maytenus fournieri, Garcinia amplexicaulis, microprobe localisation. 


\section{Introduction}

Plant hyperaccumulators exhibit rare and extreme affinity for commonly one, and less often, two or more metals or metalloids. The trait is manifest in species that remain healthy while scavenging and accumulating potentially lethal shoot-concentrations of certain metals and metalloids, notably Ni, Cd, Zn, Mn, Cu, Co, Pb, Tl Se and As. Among these are several plant micronutrients and others whose physiological roles are either unknown, or known to be phytotoxic at quite low concentrations. Hyperaccumulation thereby raises questions about plant homeostatic processes of these elements. Their foliar sequestration has been the subject of many in vivo microprobe studies, and with the exception of Mn, there have been consistent reports of highest deposition in non-photosynthetic cells (Krämer et al. 1997; Küpper et al. 2000; Mesjasz-Przybylowicz et al. 2001; Lombi et al. 2002; Robinson et al. 2003; Bidwell et al. 2004; Smart et al. 2010). Among Mn hyperaccumulators however, three distinctly different species-dependent foliar Mn detoxification strategies have been observed, including almost exclusive pooling in mesophyll tissues (Fernando et al. 2006a; 2006b; 2007; 2008a).

Around $20 \mathrm{Mn}$ hyperaccumulators are currently known worldwide, distributed almost entirely in the Western Pacific, with major centres of diversity in eastern Australia and New Caledonia (Jaffré 1977; Proctor et al. 1989; Bidwell et al. 2002; Xue et al. 2004; Mizuno et al. 2008; Yang et al. 2008; Fernando et al. 2009). They are predominantly woody species, with several in the Australian rainforest tree genus Gossia (Myrtaceae). Investigation of $G$. bidwillii (Benth.) N. Snow \& Guymer by microprobe localisation methodology has revealed its unusual foliar Mn sequestration, with highest localised concentrations of $>500 \mathrm{mM}$ in the palisade mesophyll cells (Bidwell et al. 2002; Fernando et al. 2006b). Since then, studies on Australian and New Caledonian Mn accumulators have identified three specific foliar Mn detoxification strategies. Among the latter group, Virotia neurophylla (Guillaumin) P.H. 
Weston \& A.R. Mast (Proteaceae), Maytenus fournieri ssp drakeana (Loesn.) I.H. Mueller ((Pancher \& Sebert) Loesn., Fl. N. Caled., 20:73(1996)) (Celastraceae) and Garcinia amplexicaulis Vieill. ex Pierre (Clusiaceae) have xerophytic leaf anatomies, occur on metal enriched substrates, and are native to New Caledonia; yet they exhibit contrasting foliar Mn detoxification strategies. Large cells of the multi-layered palisade mesophyll in $V$. neurophylla, and of the multiseriate hypodermis in $M$. fournieri serve almost exclusively as Mn sinks in these species, whereas the spatial distribution of foliar Mn sinks in $G$. amplexicaulis is far less heterogeneous (Fernando et al. 2006a; 2008a). Although qualitative X-ray mapping of dry samples was useful for initially locating these Mn sinks, there is an absence of detailed knowledge about their physiologies.

Not only is $\mathrm{Mn}$ one of the most nutritionally important elements known to be hyperaccumulated, it is by far the most universally abundant in soils (Graham et al. 1988). The storage of excess Mn in plant shoots is of wider interest because unlike other essential trace nutrients its accumulation of and tolerance to concentrations exceeding 'normal' physiological requirements is not uncommon, nor is this clearly understood in physiological terms (Marschner 2002; Foulds 2003). The topic of plant-Mn physiology is particularly relevant to agricultural research in regions where climatic and/or edaphic conditions render soil-Mn highly phytoavailable (Siman et al. 1974; Bromfield et al. 1983; Graham et al. 1988). Based upon data for crop plants, 'normal' foliar Mn concentrations are generally within $~ 50$ to $800 \mu \mathrm{g} \mathrm{g}^{-1}$ dry weight (dwt), whilst Mn hyperaccumulation is defined by the notional threshold value of $10,000 \mu \mathrm{g} \mathrm{g} \mathrm{g}^{-1}$ (Baker et al. 2000; Marschner 2002). Since Mn hyperaccumulators present amplified models of plant Mn tolerance, the trait might be exploited to better illuminate plant Mn detoxification. 
Further to findings on the spatial distribution of foliar Mn in Mn (hyper)accumulators, synchrotron studies have recently confirmed indirect evidence that in plants, $\mathrm{Mn}^{2+}$ is the dominant in vivo form (Bidwell et al. 2002; Xu et al. 2009; Fernando et al. 2010). It has shown that in Mn hyperaccumulators at least, carboxylate ligands such as malate, citrate and oxalate are the most likely ions counter-ions to sequestered $\mathrm{Mn}^{2+}$. Since in vivo cryo electron microprobe methodology enables the acquisition of concurrent analytical and anatomical data from fully hydrated plant tissues while minimally disrupting their homeostatic processes, it will be employed here to better understand excess Mn deposition in the leaves of $V$. neurophylla, M. fournieri and G. amplexicaulis, particularly with reference to interspecies differences in their Mn sinks and associated homeostatic ion antagonism.

\section{Materials and methods}

\section{Sample collection and cryo-fixation}

Leaf tissues previously sampled for qualitative in vivo localisation studies were used here (Fernando et al. 2008b). All three species had been collected from Grande Terre, the largest of the New Caledonian islands, where their host ultramafic lateritic soils are enriched with a range of heavy metals including $\mathrm{Fe}, \mathrm{Mn}, \mathrm{Ni}$ and $\mathrm{Cr}$. Leaves were collected directly into cool humid packaging to retain their field freshness. Within $24 \mathrm{hrs}$ they were subsampled and cryo fixed in the laboratory by rapidly freezing tissue pieces (approx. 1.0 to $0.5 \times 0.5 \mathrm{~cm}$ ) in melting nitrogen under vacuum (CT1501, Oxford Instruments, Eynsham, UK), before storage under liquid nitrogen $\left(\mathrm{LN}_{2}\right)$.

\section{Total leaf Mn analyses}

Leaves were oven dried and ground, and 0.3 to $0.5 \mathrm{~g}$ weighed into $75 \mathrm{ml}$ Pyrex ${ }^{\circledR}$ tubes to be digested in $5 \mathrm{ml} 70 \%$ nitric acid at $125^{\circ} \mathrm{C}$ for $2 \mathrm{~h}$. Digests were treated with $30 \%$ hydrogen 
peroxide, diluted to $75 \mathrm{ml}$ with distilled water, analysed and quantified using inductivelycoupled plasma optical emission spectroscopy (ICP-OES) against a series of aqueous standards acidified with nitric acid. In addition to $\mathrm{Mn}, \mathrm{Ca}$ and $\mathrm{Mg}$ were also measured since the ultramafic soils on which these species grow have unusually large $\mathrm{Mg} / \mathrm{Ca}$ concentration quotients (Jaffré 1980). For each plant species, samples with the highest Mn concentrations were selected for this study.

\section{Preparation of frozen samples for cryo-SEM work}

Cryo-fixed and frozen tissue fragments taken from $\mathrm{LN}_{2}$ cold storage were manually trimmed down to $\sim 3 \times 2 \mathrm{~mm}$ pieces using a $\mathrm{LN}_{2}$-cooled razor blade on a cold aluminium (Al) block partly immersed in a $\mathrm{LN}_{2}$ bath. Working just above the surface of this $\mathrm{LN}_{2}$ bath, cold forceps were then used to rapidly position the frozen trimmed tissue into the slit of an Al sample stub containing a small amount of cryo glue (Tissue-Tek ${ }^{\circledR}$, Sakura, Netherlands). The stub was quickly plunged into $\mathrm{LN}_{2}$ to instantly cement the sample in place. While in the $\mathrm{LN}_{2}$ bath, the stub was secured into a pre-cooled substage and transferred under $\mathrm{LN}_{2}$ to a cryoultramicrotome (Leica UltracutE/FC, Leica Microsystems, Mount Waverly, Victoria, Australia). A cold $\left(-83^{\circ} \mathrm{C}\right)$ glass knife was used to polish the $\sim 0.5 \mathrm{~mm}$ protruding frozen leaf cross-sectional surface by planing it at decreasing section thickness settings of $0.9 \mu \mathrm{m}, 0.7$ $\mu \mathrm{m}$ and finally to $0.2 \mu \mathrm{m}$; ultimately yielding a smooth mirror-like surface suitable for X-ray analysis. The substage was then removed from the microtome into a closed specimen transfer device and rapidly transferred to the SEM cold stage (JEOL JSM 840A, JEOL, Tokyo, Japan), where it was observed at $5 \mathrm{kV}$ while being lightly sublimed to improve anatomical clarity. The sample was coated with 10 to $15 \mathrm{~nm}$ of $\mathrm{Al}$ on the cold stage of the preparation chamber attached to the SEM (CT1500, Oxford Instruments, Wycombe, UK), and returned to the SEM for analysis during which it was maintained at $-169{ }^{\circ} \mathrm{C}$, and the 
anticontaminator cold plate at $-192{ }^{\circ} \mathrm{C}$. Pictorial and analytical data had to be acquired almost continuously over a 3 - 4-day period for each sample, during which it was maintained at $-169{ }^{\circ} \mathrm{C}$ on the SEM cold stage. One sample per species was considered sufficient for the purposes of this study, since leaf anatomy along with qualitative in vivo distribution of $\mathrm{Mn}$, $\mathrm{Mg}$ and $\mathrm{Ca}$ had previously been examined in replicate dry samples of the above species. Results here are to be regarded as only indicative of in vivo values, but not as absolute representations.

\section{Quantitative X-ray mapping and selected area analyses}

The SEM was equipped with a Link (Oxford Instruments, Eynsham, UK) LZ4 $30 \mathrm{~mm}^{2}$ lithium (Li)-drifted silicon (Si) X-ray detector interfaced to a Link eXL X-ray analytical system. The beryllium (Be) window was used in the detector whose take-off and solid angles were respectively $40^{\circ}$ and 0.011 steradians. The Link X-ray imaging software for quantitative mapping calculates peak integrals, using multiple least squares fitting of library peaks to the spectrum for each pixel, and apparent concentrations i.e. concentrations that have not been corrected for matrix effects. Apparent concentration images were corrected arithmetically to true concentration images by applying matrix corrections that were derived from static beam analyses of the same samples. The Phi-Rho-Zed model developed by Bastin et al. (1986) as applied to biological samples (Marshall 1982) was used to obtain quantitative analyses. The standards used for elements $\mathrm{Z}>10$ were polished microprobe standards (Bio-Rad Laboratories, Gladesville, NSW, Australia). Fixed concentrations of unanalysed elements $(\mathrm{H}, \mathrm{C}, \mathrm{O}, \mathrm{N})$ were used in the calculation of matrix corrections assuming that cell lumen contained $98 \%$ water. Depending upon magnification, X-ray maps were collected at 
resolutions of $64 \times 64$ or $128 \times 128$ pixels with respective dwell times of $6 \mathrm{~s}$ or $1.5 \mathrm{~s}$ per pixel.

Quantitative $\mathrm{Mn}, \mathrm{Mg}, \mathrm{K}, \mathrm{S}, \mathrm{Cl}, \mathrm{P}$ and $\mathrm{Ca} \mathrm{X}$-ray maps were obtained at an accelerating voltage of $15 \mathrm{kV}$, with an approximate beam current of $5 \times 10^{-9} \mathrm{~A}$. For each of these maps, the gain calibration was performed on a $\mathrm{Cu}$ grid attached to the SEM stage, which was focused electronically. Thereafter the sample area selected for analysis was focused only via the mechanical Z (stage height) control, with no electronic focussing changes made, so that the sample surface remained in an optimal plane for analysis and the X-ray take off angle did not change. Prior to acquiring each map, a secondary electron image (SEI) of the sample area was saved.

The X-ray maps and their corresponding SEI were used to confirm major Mn storage sites in Mn maps that had been identified in previous studies using dry samples (Fernando et al. 2006a; 2008b). Where there was clear indication from the maps of highest localised concentrations, these sites, all on cell lumen, were then quantified by selective area analyses. For each cell type, data were obtained from $4-19$ replicate cells. Consistency of replication was governed by the availability of data free of electrical charging effects, and the maintenance of comparable dead-times and spectral shapes consistent with the watery matrix of cell lumen. Since qualitative maps of G. amplexicaulis had previously indicated that $\mathrm{Mn}$ is distributed relatively evenly across the leaf with no apparent major Mn pools, it was expected that for this species all cell types would be quantified. It was also expected that $M$. fournieri sinks were in the hypodermis and to a lesser extent in the region of the lower epidermis, while in $V$. neurophylla primary Mn sequestration was expected to occur in the palisade cells. Although Mn distributions for species examined here had previously been identified, in this 
study the sample preparation and mode of mapping was designed to provide more detailed data.

In vivo elemental concentrations for the chosen Mn storage cells were obtained by selected area analyses using the Phi-rho-zed model for quantitation. Given the very low moisture content of cuticular tissue (Becker et al. 1986), and that it was metabolically the least important tissue to be examined here, quantitative data were not obtained. For all other tissues, quantitative datasets for individual cells were obtained using an adjustable raster to select areas well within cell wall boundaries.

\section{Statistical analyses}

For each cell type examined, replicate data were pooled to obtain mean elemental concentrations and standard errors (Table 2). Regression analyses were performed using Mn concentrations as the independent variable against the other elemental concentrations.

\section{Results}

Data obtained from ICP leaf chemical analyses (Table 1) confirmed that the species examined here had extremely high foliar Mn concentrations warranting their classification as Mn hyperaccumulators. Secondary electron images (SEIs) of frozen hydrated leaf crosssectional surfaces showed anatomical features corresponding to X-ray maps that were consistent with previously obtained data (Figs 1-3) (Fernando et al. 2006a; 2008b). All X-ray maps (Figs 1-4) are quantitative elemental images scaled for optimum contrast so that pixel intensities represent accurate concentration differences within a single image but differences in pixel intensity between images do not accurately represent concentration differences between elements. Major Mn sequestration sites were in the palisade cells of $V$. neurophylla; 
and in the hypodermal layers and lower epidermis of M. fournieri. Excess foliar Mn in the latter was confined almost exclusively to the large watery vacuoles of non-photosynthetic hypodermal cells, as evidenced by the sharply delineated Mn maps (Fig 4b). The equally distinct Mn maps of $V$. neurophylla palisade cells (Fig 4a) not only clearly delineated their large vacuolar volumes, but also negatively outlined chloroplasts confined to narrow cytoplasmic regions surrounding these vacuoles, where they were 'sandwiched' between the cell walls and voluminous vacuoles. The thermal colour scale used in these maps (Fig 4) highlights distinct cytoplasmic regions in $V$. neurophylla palisade cells, i.e. the red border around the bright yellow Mn-loaded vacuoles (4a), whereas the Mn-loaded cells in $M$. founieri seem entirely vacuolar in content. It also appeared that the high $\mathrm{Mn}$ content of the $V$. neurophylla palisade cells provided atomic number contrast to the SEI (Fig 4a), making them appear 'brighter'.

As expected, in G. amplexicaulis Mn was distributed least heterogeneously across the leaf cross section. Quantitative selected-area analyses (Table 2) showed that V. neurophylla palisade cells had a mean $\mathrm{Mn}$ concentration of over $650 \mathrm{mM}$, similar to that of the spongy mesophyll cells of G. amplexicaulis. There was a narrow subepidermal cell layer between the second upper epidermal and first palisade cell layers in the G. amplexicaulis leaf crosssection whose mean localised Mn concentration $>800 \mathrm{mM}$ was the highest observed. The two palisade and lower epidermal layers of G. amplexicaulis had Mn concentrations of $\sim 200$ $\mathrm{mM}$, with much lower concentrations of around 15 to $50 \mathrm{mM} \mathrm{Mn}$ in the two upper epidermal layers. In M. fournieri the upper and lower hypodermal cell layers had respective localised Mn concentrations of over 500 and $600 \mathrm{mM}$, whilst the lower epidermal cells had an estimated mean Mn concentration of around $200 \mathrm{mM}$. The upper cuticle of G. amplexicaulis 
and the lower cuticle of $M$. fournieri leaves were found by X-ray mapping to contain $\mathrm{Mn}$ (Figs 3, 2).

Regression data (Table 3) and/or the X-ray maps show: a) an overall negative Mn-K correlation across most cell types of all species examined, except for G. amplexicaulis second layer palisade cells and lower epidermal cells; b) a positive $\mathrm{Mn}-\mathrm{S}$ correlation in $V$. neurophylla palisade cells; c) a negative $\mathrm{Mn}-\mathrm{S}$ correlation in the first layer upper epidermal cells of $G$. amplexicaulis; d) a slight positive $\mathrm{Mn}-\mathrm{Ca}$ correlation in the dermal tissues of $M$. fournieri and G. amplexicaulis; e) positive $\mathrm{Mn}-\mathrm{Mg}$ correlations in $M$. fournieri first layer hypodermal cells and $G$. amplexicaulis second layer palisade cells; f) negative $\mathrm{Mn}-\mathrm{Mg}$ correlations in G. amplexicaulis first layer upper epidermal cells; and g) a negative $\mathrm{Mn}-\mathrm{Cl}$ correlation in the first layer upper epidermal cells, and in subepidermal cells between the upper epidermis and palisade tissues of G. amplexicaulis. Mean localised P concentrations across all cell-types ranged between 0.032 and $26.6 \mathrm{mM}$, however due to unacceptable statistical variation these data were excluded from Table 2. Foliar P distribution patterns for all three species as observed by X-ray mapping (Figs 1-3) were relatively featureless, mutually similar, and bore no clear relationship to $\mathrm{Mn}$.

\section{Discussion}

Detoxification in metal-accumulating plants is determined by a range of factors including metal transporters, metal chelators, vacuolar volume, other leaf anatomical features, potential phytotoxicities of hyperaccumulated elements, and possibly even guttation (Clemens 2001; Broadhurst et al. 2004; Fernando et al. 2006b; 2008a; Montargés-Pelletier et al. 2008; Smart et al. 2010). The three woody species examined here share very similar geographic 
distributions and xerophytic leaf traits; yet exhibit markedly different foliar Mn sequestration patterns. Whilst in agreement with previous qualitative investigations, this study further illuminates the nature of foliar $\mathrm{Mn} \operatorname{sinks}$ in $V$. neurophylla, M. fournieri and $G$. amplexicaulis. Data were obtained from hydrated plant tissues preserved closest to their normal living state as was achievable from all available sample preparation techniques, with their metabolic processes immobilised to represent a true in vivo 'snapshot' of homeostasis. For this investigation, the limitations of examining tissues in their in vivo hydrated states included a) elements solubilised in cell lumen would be more dilute and therefore more difficult to detect than those in dry samples prepared by methods such as freeze substitution, and/or b) the poorer anatomical resolution of wet samples. These considerations were however outweighed by the need to gather as much information as possible from 'living' tissue prior to attempting studies utilising higher resolution dry sample preparations. Additionally, it was essential to avoid the artefactual loss and/or displacement of elements from the cell lumen, in particular lighter elements such as $\mathrm{K}$ for example. It is well established (Lauchli et al. 1970; Pallaghy 1973; Marshall 1980b) that their in vivo distributions are easily disrupted by certain solvents including acetone commonly employed in the resin infiltration of dry samples.

It was clarified that $\mathrm{Mn}$ pools almost exclusively in the photosynthetically important palisade mesophyll cells of $V$. neurophylla, and in the non-photosynthetic hypodermal cells of $M$. fournieri, both of which are highly vacuolated. Not only were these Mn-rich sinks in their fully hydrated states clearly delineated in Mn X-ray maps, but in the former species, this high Mn content provided inherent electronic contrast to the secondary electron image (Fig 4a), a phenomenon rarely encountered in plant electron microscopy. Whereas primary Mn-storage cells of $V$. neurophylla and $M$. fournieri were much larger than other cells in their leaf tissues, 
G. amplexicaulis leaves lacked this obviously large cell-size discrepancy (Fig 3) and exhibited relatively homogeneous Mn distribution across all cell types. Inference from these observations is that either one or both of the following criteria influence foliar $\mathrm{Mn}$ detoxification strategies in the plants examined here: a) vacuolar volume likely takes precedence over cell metabolic importance, b) Mn is an important plant nutrient integral to photosynthesis not uncommonly tolerated in concentrations exceeding normal physiological requirements, and therefore can be regarded as 'less toxic' than other trace metals such as for example as Ni.

Whilst foliar Mn in the hyperaccumulator G. bidwillii is distributed through all cell types including small epidermal cell vacuoles, it is by far the most highly localised in large palisade cells. Interestingly, in the Mn-accumulating Grevillea exul Lindley (Proteaceae) it is the large epidermal cell vacuoles rather than large palisade cells that act as primary $\mathrm{Mn}$ deposition sites (Fernando et al. 2006b; 2008b). Based on the above arguments, this latter observation could be indicative of cell metabolic importance driving sequestration when similarly large vacuolar volumes are available in both the photosynthetic and nonphotosynthetic cells. Previous light microscopical data (Fernando et al. 2008b) have shown that the G. amplexicaulis subepidermal cells found here to contain the highest mean $\mathrm{Mn}$ concentrations of over $800 \mathrm{mM}$ were non-photosynthetic, and therefore most likely to be small hypodermal cells functionally similar to the large $M$. fournieri hypodermal cells. It is noteworthy then that the hypodermis, where present, plays an important role in storing excess Mn.

In the herbaceous Mn hyperaccumulator Phytolacca acinosa Roxb. (Phytolaccaceae), Mn is highly localised in leaf epidermal tissues (Xu et al. 2006). Little information is provided 
about leaf anatomy, and it appears to consist of cells lacking any obvious size discrepancy. There are numerous microprobe localisation studies on $\mathrm{Ni}, \mathrm{Cd}$ and $\mathrm{Zn}$ hyperaccumulation by members of the Brassicaceae family, which overwhelmingly indicate that dermal tissues are primary sinks, in particular, epidermal cell vacuoles and leaf hairs and trichomes (Krämer et al. 2000; Küpper et al. 2000; Bidwell et al. 2004; Broadhurst et al. 2004; Asemaneh et al. 2006). An apparent absence of variation in the foliar distribution patterns of hyperaccumulated metals other than $\mathrm{Mn}$ is not readily explicable. As to whether this might be associated with the important nutritional role of $\mathrm{Mn}$ and/or its relatively wide tolerance by plants is not easy to resolve. These discussions also highlight the need for a clearer understanding of tonoplastal Mn transporters in Mn hyperaccumulators.

On comparison of total leaf concentrations to palisade cell Mn concentrations, values obtained here, i.e. a palisade vacuolar $\mathrm{Mn}$ concentration of $\sim 600 \mathrm{mM}$ in $V$. neurophylla $\left(31,200 \mu \mathrm{g} \mathrm{g}^{-1}\right.$ total leaf $\left.\mathrm{Mn}\right)$ and $200 \mathrm{mM}$ in G. amplexicaulis $\left(13,100 \mu \mathrm{g} \mathrm{g}^{-1}\right.$ total leaf $\left.\mathrm{Mn}\right)$ are in reasonable agreement with similar previous studies on $G$. bidwillii $\left(\sim 22,000 \mu \mathrm{g} \mathrm{g}^{-1}\right.$ total leaf Mn) whose palisade cells were $>500 \mathrm{mM}$ Mn (Fernando et al. 2006b). Given that in these three species the palisade mesophyll probably accounts for 20 to $30 \%$ of the total leaf volume, an estimate based on visual inspection of leaf anatomical data (SEIs in Figs 1-3), these palisade Mn concentrations appear to reflect their corresponding total leaf $\mathrm{Mn}$ concentrations. The hypodermal cells of $M$. fournieri $\left(20,150 \mu \mathrm{g} \mathrm{g} \mathrm{g}^{-1}\right.$ total leaf $\left.\mathrm{Mn}\right)$ containing around $600 \mathrm{mM} \mathrm{Mn}$ occupy a similar proportion of the total leaf volume. Estimatates of Mn vacuolar concentrations obtained in this study are reasonably consistent with those previously obtained in a far more detailed study of G. bidwillii that employed similar methodology (Fernando et al. 2006b). 
Elevated foliar Ca concentrations observed here in both $M$. fournieri and G. amplexicaulis (Table 1) were likely due in part at least to the high Ca content of their dermal tissues, as indicated by qualitative and quantitative X-ray data (Table 2). However this does not fully explain the observation here of five- and four-fold differences respectively in their foliar $\mathrm{Ca}$ concentrations compared to $V$. neurophylla. Raphide cells loaded with Ca-oxalate crystals have previously been observed in G. bidwillii leaves (Fernando et al. 2006b), and here might account for the very bright cells in the Ca X-ray maps (Figs 1-3). The prevalence of Caoxalate may noticeably elevate total leaf Ca concentrations. Cell walls generally do contain more $\mathrm{Ca}$ than the lumen, and this is amplified in xerophytic species where dermal fortification is common (Esau 1965; Taiz and Zeiger 2002). X-ray maps obtained here (Figs 1-3) showed Ca outlining cell shapes, i.e. in their cell walls. The predominant in vivo ionic forms of $\mathrm{Ca}$ and $\mathrm{Mn}, \mathrm{Ca}^{2+}$ and $\mathrm{Mn}^{2+}$, have similar radii, which can lead to competitive ionic antagonism (Marschner 2002). Hence, the positive Mn-Ca correlation observed in the upper epidermal and hypodermal cells of G. amplexicaulis might be explained this way. A similar argument applies to $\mathrm{Mn}^{2+}-\mathrm{Mg}^{2+}$ antagonism, as evidenced in the positive $\mathrm{Mn}-\mathrm{Mg}$ correlation in the hypodermal cells of M. fournieri and palisade cells of G. amplexicaulis. However, it does not explain the negative $\mathrm{Mn}-\mathrm{Mg}$ correlation in G. amplexicaulis upper epidermal cells.

A negative Mn-K correlation in the large spongy mesophyll section of G. amplexicaulis leaf tissue suggested that $\mathrm{K}^{+}$in these cells was reduced by their $\mathrm{Mn}$ accumulation. Unlike palisade mesophyll cells, spongy mesophyll cells are usually most important for respiration, and generally have relatively less vacuolar volume and greater cytoplasm with a high $\mathrm{K}^{+}$ content. As observed here, xerophytic leaf anatomies characteristically lack intercellular spaces in the spongy mesophyll; and for this species where the anatomical SEI (Fig 3) does not show significant differences between palisade and spongy mesophyll cells, it is not 
implausible then that these cell types might be relatively similar. Ultrastructural studies are needed to evaluate their vacuolar/cytoplasmic ratios, and thereby hypothesise about observations of Mn-K relationships. Were the vacuolar contents of these spongy mesophyll cells unusually large, they might be capable of Mn storage at the expense of respiration. In the authors' experience, preparation of these leaf tissues for transmission electron microscopical ultrastructural studies was precluded by tissue impermeability to resins due their thickness and sclerophylly. Species examined here are therefore likely unsuited to dry sample microprobe techniques, unlike herbaceous hyperaccumulators to which they have thus far been applied.

Negative $\mathrm{Mn}-\mathrm{K}$ correlations were also found in the $M$. fournieri hypodermis and $G$. amplexicaulis upper epidermis, both relatively unimportant to essential metabolic processes, and therefore unlikely to have significant cytoplasmic content. $\mathrm{K}^{+}$is known to play an important role in balancing negative ions in the cytoplasm and vacuole (Jeschke et al. 1985), and its accumulation can result in build-up of organic acid counter anions. Whether $\mathrm{Mn}^{2+}$ accumulated in the spongy mesophyll replaces $\mathrm{K}^{+}$to some extent in counterbalancing negative ions cannot be determined, and requires further investigation via ultrastructural in vivo microprobe methodologies. The role of $\mathrm{K}^{+}$in maintaining vacuolar turgor pressure (Lindhauer 1985, 1987) might in these species be replaced by $\mathrm{Mn}^{2+}$, which would also explain the negative Mn-K correlation. Similar previous studies of G. bidwillii have shown a Mn-K negative correlations in Mn-rich palisade cells and Mn-containing epidermal cells (Fernando et al. 2006b). Qualitative X-ray maps of fixed dried V. neurophylla leaf crosssections indicating a negative Mn-K relationship (Fernando et al. 2006a) were in agreement with the quantitative X-ray maps obtained here (Fig 1). However, this was not reflected in current quantitative data gathered from palisade cells (Table 3). Positive Mn-K correlations 
detected in G. amplexicaulis palisade and lower epidermal cells might be due to increased $\mathrm{K}^{+}$ in response to the presence of excess organic acid anions, which in turn is a possible response to accumulated $\mathrm{Mn}^{2+}$ (Marschner 2002).

Although the strong Mn-S positive correlation observed here in V. neurophylla Mn-loaded palisade cell vacuoles might indicate an association between S-containing counter-ions and Mn, involvement of an organic acid or a phytochelatin is unlikely, firstly because the localised S (33 mM) does not quantitatively account for co-localised $\mathrm{Mn}(683 \mathrm{mM})$, and also for reasons discussed below. It is noteworthy that a positive $\mathrm{Mn}-\mathrm{S}$ correlation was also found in a prior quantitative cryo-SEM EDS study of G. bidwillii (Fernando et al. 2006b); and also that synchrotron data (Fernando et al. 2010) have linked carboxylate ligands to $\mathrm{Mn}^{2+}$ in both freeze-dried $V$. neurophylla and $G$. bidwillii leaf tissues. It discounted the role of Scontaining ligands such as histdine in binding excess foliar Mn. Furthermore, observation here of accumulated $\mathrm{S}$ is unlikely due to Mn-binding phytochelatins since it is well established that in $\mathrm{Cd}, \mathrm{Ni}$ and As hyperaccumulators at least, phytochelatins do not play a major role, and that they are often linked to homeostasis of trace elements in nonaccumulating plants. Correlation between glutathione and metal accumulation has however been observed in certain $\mathrm{Ni}, \mathrm{Cu}, \mathrm{Cd}$ and $\mathrm{Zn}$-hyperaccumulating species (Freeman et al. 2004; Sun et al. 2007; Na and Salt 2011). The role of inorganic S in binding excess Mn should also be considered as a possibility. As pointed out in the Materials and Methods, quantitative Xray data were only collected from the cell lumen. There was considerable discrepancy between localised vacuolar S concentrations previously obtained for a range of G. bidwillii cell-types $(1.9-28.6 \mathrm{mM})$; and those obtained here for a variety of $G$. amplexicaulis cells $(20-253 \mathrm{mM})$ as well as the multiseriate dermal cells of $M$. fournieri $(69-127 \mathrm{mM})$. While no significant $\mathrm{Mn}-\mathrm{S}$ correlations were observed for the latter two species, it is interesting that 
some of the highest observed localised S concentrations were concurrent with highly elevated Mn concentrations.

In summary, this investigation demonstrated that specific variation in foliar Mn spatial distribution patterns is linked at least in part to plant tolerance to $\mathrm{Mn}$, available vacuolar volume and the metabolic importance of sink host-cells. Positive $\mathrm{Mn}-\mathrm{Ca}$ and $\mathrm{Mn}-\mathrm{Mg}$ antagonism and negative $\mathrm{Mn}-\mathrm{K}$ antagonism were likely associated with homeostatic ion function of $\mathrm{Ca}^{2+}, \mathrm{Mg}^{2+}$ and $\mathrm{K}^{+}$. While this study sought to identify linear elemental interrelationships associated with localised $\mathrm{Mn}$, it is possible that $\mathrm{Mn}$ pooling gave rise to other more complex antagonistic effects, the detection of which were outside the scope of this study. It was shown here that although vacuolar sequestration is the main mode of $\mathrm{Mn}$ detoxification in all three species examined, its binding is variable, notably in $V$, neurophylla. By detailing them in a manner closest to their living states, wet sample electron microscopy has provided unique insight into Mn sinks in these Mn hyperaccumulators. It has highlighted the need to better understand Mn specificity and the apparent ability of metabolically important cells to safely compartmentalise soluble $\mathrm{Mn}$ in highly localised and otherwise phytotoxic concentrations.

\section{Acknowledgements}

This research was funded by the University of Melbourne and La Trobe University. The authors thank Vincent Dumontet and the late Nicolas Perrier for their help and expertise in identifying plants in the field. DRF acknowledges the University of Melbourne David Hay Award for financial contribution towards preparation of this manuscript. 


\section{References}

Arnetoli M, Vooijs R, Bookum W, Galardi F, Gonnelli C, Gabrielli R, Schat H, Verkleij JAC (2008) Arsenate tolerance in Silene paradoxa does not rely on phytochelatindependent sequestration. Environmental Pollution 152: 585-591

Asemaneh T, Ghaderian SM, Crawford SA, Marshall AT, Baker AJM (2006) Cellular and subcellular compartmentation of $\mathrm{Ni}$ in the Eurasian serpentine plants Alyssum bracteatum, Alyssum murale, (Brassicaceae) and Cleome heratensis (Capparaceae). Planta 225: 193-202

Baker AJM, McGrath SP, Reeves RD, Smith JAC (2000) Metal hyperaccumulator plants: a review of the ecology and physiology of a biological resource for phytoremediation of metal-polluted soils. In N Terry, G Bañuelos, eds, Phytoremediation of Contaminated Soil and Water. CRC Press LLC, Boca Raton, Florida, pp 85-108

Bastin GF, Heijligers JM, Loo FJJv (1986) A further improvement in the Gaussian Phi-RhoZed approach for matrix correction in quantitative electron probe microanalysis. Scanning 8: 45-67

Becker M, Kerstiens G, Schonherr J (1986) Water permeability of plant cuticles: permeance, diffusion and partition coefficients. Trees - Structure and Function 1: 54-60

Bidwell SD, Crawford SA, Woodrow IE, Sommer-Knusden J, Marshall AT (2004) Subcellular localization of $\mathrm{Ni}$ in the hyperaccumulator Hybanthus floribundus (Lindley) F. Muell. Plant Cell and Environment 27: 705-716

Bidwell SD, Woodrow IE, Batianoff GN, Sommer-Knusden J (2002) Hyperaccumulation of manganese in the rainforest tree Austromyrtus bidwillii (Myrtaceae) from Queensland, Australia. Functional Plant Biology 29: 899-905

Broadhurst CL, Chaney RL, Angle JS, Maucel TK, Erbe EF, Murphy CA (2004) Simultaneous hyperaccumulation of nickel, manganese and calcium in Alyssum leaf trichomes. Environmental Science and Technology 38: 5797-5802

Bromfield SM, Cumming RW, David DJ, Williams CH (1983) Change in soil pH, manganese and aluminium under subterranean clover pasture. Australian Journal of Agricultural Animal Husbandry 23: 181-191

Clemens (2001) Molecular mechanisms of plant metal tolerance and homeostasis. Planta 212: 475-486

DeKnecht JA, Koevoets PLM, Verkleij JAC, Ernst WHO (1992) Evidence against a role for phytochelatins in naturally selected increased cadmium tolerance in Silene vulgaris (Moench) Garcke. New Phytologist 122: 681-688

Esau K (1965) Plant Anatomy. John Wiley \& Sons Inc, New York

Fernando DR, Bakkaus EJ, Perrier N, Baker AJM, Woodrow IE, Batianoff GN, Collins RN (2006a) Manganese accumulation in the leaf mesophyll of four tree species: a PIXE/EDAX localization study. New Phytologist 171: 751-758

Fernando DR, Batianoff GN, Baker AJ, Woodrow IE (2006b) In vivo localisation of manganese in the hyperaccumulator Gossia bidwillii (Benth.) N. Snow \& Guymer (Myrtaceae) by cryo-SEM/EDAX. Plant, Cell and Environment 29: 1012-1020

Fernando DR, Guymer G, Reeves RD, Woodrow IE, Baker AJ, Batianoff GN (2009) Foliar Mn accumulation in eastern Australian herbarium specimens: prospecting for 'new' Mn hyperaccumulators and its potential application in taxonomy. Annals of Botany 103: 931-939

Fernando DR, Marshall AT, Gouget B, Carriere M, Collins RN, Woodrow IE, Baker AJ (2008a) Novel pattern of foliar metal distribution in a manganese hyperaccumulator. Functional Plant Biology 35: 1-8 
Fernando DR, Marshall AT, Gouget B, Carrière M, Collins RN, Woodrow IE, Baker AJ (2008b) Novel Pattern of foliar metal distribution in a manganese hyperaccumulator. Functional Plant Biology 35: 193-200

Fernando DR, Mizuno T, Woodrow IE, Baker AJM, Collins RN (2010) Characterization of foliar manganese (Mn) in Mn (hyper)accumulators using X-ray absorption spectroscopy. New Phytologist 188: 1014-1027

Fernando DR, Woodrow IE, Jaffré T, Dumontet V, Marshall AT, Baker AJM (2007) Foliar Mn accumulation by Maytenus founieri (Celastraceae) in its native New Caledonian habitats: populational variation and localisation by X-ray microanalysis. New Phytologist 177: 178 -185

Foulds W (2003) Nutrient concentrations of foliage and soil in south-western Australia. New Phytologist 125: 529-546

Freeman JL, Persans MW, Nieman K, Albrecht C, Peer W, Pickering IJ, Salt DE (2004) Increased glutathione biosynthesis plays a role in nickel tolerance in Thlaspi nickel hyperaccumulators. The Plant Cell 16: 2176-2191

Graham RD, Hannam RJ, Uren NC (1988) Manganese in Soils and Plants. In R D Graham, R J Hannam, N C Uren, eds, International Symposium on Manganese in Soils and Plants. Kluwer Academic Press, Glen Osmond, South Australia

Jaffré T (1977) Accumulation du manganèse par des especes associées aux terrains ultrabasiques de Nouvelle-Calédonie. Comptes Rendus Academie des Science, Paris 284: 1573-1575 Série D

Jaffré T (1980) Etude écologique du peuplement végétal des sols dérivés de roches ultrabasiques en Nouvelle-Caledonie. ORSTOM, Paris

Jeschke WD, Atkins CA, Pate JS (1985) Ion circulation via phloem and xylem between root and shoot of nodulated white lupin. Journal of Plant Physiology 117: 319-330

Krämer U, Grime GW, Smith JAC, Hawes CR, Baker AJM (1997) Micro-PIXE as a technique for studying nickel localization in leaves of the hyperaccumulator Alyssum lesbiacum. Nuclear Instruments and Methods in Physics Research B- Beam Interactions with Materials and Atoms 130: 346-350

Krämer U, Pickering IJ, Prince RC, Raskin I, Salt DE (2000) Subcellular localization and speciation of nickel in hyperaccumulator and non-accumulator Thlaspi species. Plant Physiology 122: 1343-1353

Küpper H, Lombi E, Zhao F, McGrath SP (2000) Cellular compartmentation of cadmium and zinc in relation to other elements in the hyperaccumulator Arabidopsis halleri. Planta 212: 75-84

Lauchli A, Spurr AR, Wittkopp RW (1970) Electron probe analysis of freeze-substituted, epoxy resin embedded tissue for ion transport studies in plants. Planta 95: 341-350

Lindhauer MG (1985) Influence of K nutrition and drought on water relations and growth of sunflower (Helianthus annuus L.). Zeitschrift für Pflanzenernährung und Bodenkunde 148: 654-659

Lindhauer MG (1987) Solute concentrations in well-watered and water-stressed sunflower plants differing in K nutrition. Journal of Plant Nutrition 10: 1965-1973

Lombi E, Zhao FJ, Fuhrmann M, Ma LQ, McGrath SP (2002) Arsenic distribuition and speciation in the fronds of the hyperaccumulator Pteris vittata. New Phytologist 156: 195-203

Marschner H (2002) Mineral Nutrition of Higher Plants. Academic Press, London

Marshall AT (1980b) Freeze-substitution as a preparation technique for biological X-ray microanalysis. Scanning Electron Microscopy II: 395-408 
Marshall AT (1982) Application of O ( $f$ Ïz) curves and a windowless detector to the quantitative $x$-ray microanalysis of frozen-hydrated bulk biological specimens. Scanning Electron Microscopy 1: 243-260

Mesjasz-Przybylowicz J, Przybylowicz WJ, Pineda CA (2001) Nuclear microprobe studies of elemental distribution in apical leaves of the Ni hyperaccumulator Berkheya coddii. South African Journal of Science 97: 591-593

Mizuno T, Asahina R, Hosono A, Tanaka A, Senoo K, Obata H (2008) Age-dependent manganese hyperaccumulation in Chengiopanax sciadophylloides (Araliaceae). Journal of Plant Nutrition 31: 1811-1819

Montargés-Pelletier E, Chardot V, Echevarria G, Michot LJ, Bauer A, Morel J-L (2008) Identification of nickel chelators in three hyperaccumulating plants: An X-ray spectroscopic study. Phytochemistry 69: 1695-1709

$\mathrm{Na} \mathrm{G}$, Salt DE (2011) The role of sulfur assimilation and sulfur-containing compounds in trace element homeostasis in plants. Environmental and Experimental Botany 72: 1825

Pallaghy CK (1973) Electron probe microanalysis of potassium and chloride in freezesubstututed leaf sections of Zea mays. Australian Journal of Biological Science 26: 1015-1034

Proctor J, Phillips C, Duff GK, Heany A, Robertson FM (1989) Ecological studies on Gunung Silam, a small ultrabasic mountain in Sabah, Malaysia. II. Some forest processes. Journal of Ecology 77: 317-331

Robinson BH, Lombi E, Zhao FJ, McGrath SP (2003) Uptake and distribution of nickel and other metals in the hyperaccumulator Berkheya coddii. New Phytologist 158: 279-285

Schat H, Llugany M, Vooija R, Hartley-Whitaker J, Bleeker PM (2002) The role of phytochelatins in constitutive and adaptive heavy metal tolerances in hyperaccumulator and nonhyperaccumulator metallophytes. Journal of Experimental Botany 53: 2381-2392

Shah A, Shigeru K, Shigenao k (2000) Phytosiderosphore release from manganese-induced iron deficiency in barley. Journal of Plant Nutrition 23: 1193-1207

Siman A, Cradock FW, Hudson AW (1974) The development of manganese toxicity in pasture legumes under extreme climatic conditions. Plant and Soil 41: 129-140

Smart KE, Smith JAC, Kilburn MR, Martin BGH, Hawes C, Grovenor CRM (2010) Highresolution elemental localization in vacuolate plant cells by nanoscale secondary ion mass spectrometry. The Plant Journal 63: 870-879

Sun RL, Zhou QX, Sun FH, Jin CX (2007) Antioxidative defense and proline/phytochelatin accumulation in a newly discovered Cd-hyperaccumulator, Solanum nigrum L. Environmental and Experimental Botany 60: 468-476

Taiz L, Zeiger E (2002) Plant Physiology, Ed Third Edition. Sinauer Associates, Inc, Sunderland, USA

Xu X, Shi J, Chen X, Chen Y, Hu T (2009) Chemical forms of manganese in the leaves of manganese hyperaccumulator Phytolacca acinosa Roxb. (Phytolaccaceae). Plant and Soil 318: 197-204

Xu X, Shi J, Chen Y, Chen X, Wang H, Perera A (2006) Distribution and mobility of manganese in the hyperaccumulator plant Phytolacca acinosa Roxb. (Phytolaccaceae). Plant and Soil 285: 323-331

Xue SG, Chen YX, Reeves RD, Baker AJM, Lin Q, Fernando DR (2004) Manganese uptake and accumulation by the hyperaccumulator plant Phytolacca acinosa Roxb. (Phytolaccaceae). Environmental Pollution 131: 393-399

Yang SX, Deng H, Li MS (2008) Manganese uptake and accumulation in a woody hyperaccumulator, Schima superba. Plant Soil Environment 54: 441-446 
Table 1 Leaf tissue dry weight concentrations

\begin{tabular}{|lccc|}
\hline \multicolumn{1}{|c}{ Plant species } & Mn $\left(\mu \mathrm{g} \mathrm{g}^{-1}\right)$ & $\mathbf{C a}\left(\mu \mathrm{g} \mathrm{g}^{-1}\right)$ & $\mathbf{M g}\left(\mu \mathrm{g} \mathrm{g}^{-1}\right)$ \\
V. neurophylla & 31,200 & 5000 & 1120 \\
M. fournieri & 20,150 & 25,600 & 5100 \\
G. amplexicaulis & 13,100 & 21,100 & 1230 \\
\hline
\end{tabular}

Table 2: Localised foliar elemental concentrations as estimated from SEM EDS selected-area analyses. For qualitative data corresponding to cuticle tissues, '+' and '++' respectively denote 'detected' and 'strongly detected'. 


\begin{tabular}{|c|c|c|c|c|c|c|c|}
\hline \multirow{2}{*}{ Plant } & \multirow{2}{*}{$\begin{array}{l}\text { Cell type } \\
\text { replicates (n) }\end{array}$} & \multicolumn{6}{|c|}{ Mean concentration $(\mathrm{mM}) \pm \mathrm{se}$} \\
\hline & & Mg & $\mathrm{S}$ & $\mathrm{Cl}$ & K & $\mathrm{Ca}$ & Mn \\
\hline \multicolumn{8}{|c|}{ V. neurophylla } \\
\hline & palisade $1 \& 2$ & 14.4 & 33.3 & 4.09 & 9.92 & 13.7 & 683 \\
\hline & $(n=10)$ & 1.24 & 3.1 & 1.06 & 0.95 & 1.89 & 38.5 \\
\hline \multicolumn{8}{|c|}{ G. amplexicaulis } \\
\hline & upper cuticle & + & + & + & + & ++ & + \\
\hline & upper epidermis 1 & 17.6 & 45.1 & 142 & 121 & 109 & 46.3 \\
\hline & $(n=4)$ & 1.05 & 6.18 & 15.4 & 16.3 & 24.4 & 12.1 \\
\hline & upper epidermis 2 & 10.9 & 58 & 192 & 115 & 37.4 & 16.7 \\
\hline & $(n=4)$ & 1.54 & 2.37 & 14.8 & 9.76 & 11.7 & 5.44 \\
\hline & subepidermis & 118 & 253 & 300 & 65.3 & 121 & 876 \\
\hline & $(n=5)$ & 14.9 & 48.6 & 27.5 & 10.4 & 34.5 & 58.9 \\
\hline & palisade 1 & 24 & 148 & 59.3 & 40.3 & 43.2 & 170 \\
\hline & $(n=9)$ & 2.63 & 11.6 & 7.32 & 5.91 & 3.41 & 5.09 \\
\hline & palisade 2 & 21 & 113 & 85.5 & 21.9 & 36.8 & 242 \\
\hline & $(n=10)$ & 3.11 & 11.8 & 6.41 & 1.41 & 5.06 & 7.75 \\
\hline & spongy mesophyll & 74.5 & 212 & 414 & 102 & 119 & 681 \\
\hline & $(n=19)$ & 7.72 & 18.4 & 22.8 & 11 & 13.3 & 36.4 \\
\hline & lower epidermis & 85.6 & 223 & 231 & 101 & 426 & 199 \\
\hline & $(n=4)$ & 10.1 & 30.2 & 45.6 & 44.1 & 34.4 & 26.2 \\
\hline \multicolumn{8}{|c|}{ M. fournieri } \\
\hline & hypodermis 1 & 90.8 & 20 & 11.9 & 53.4 & 11.4 & 546 \\
\hline & $(n=10)$ & 8.73 & 1.52 & 2 & 3.27 & 2.19 & 21.4 \\
\hline & hypodermis 2 & 127 & 28.7 & 13.9 & 28.2 & 10.6 & 676 \\
\hline & $(n=10)$ & 7.26 & 0.923 & 3.27 & 4.44 & 1.71 & 23.4 \\
\hline & lower epidermis & 69.4 & 22 & 5.53 & 98.1 & 37.3 & 224 \\
\hline & $(n=10)$ & 14.7 & 2.11 & 1.27 & 13.5 & 7.17 & 29.6 \\
\hline & lower cuticle & + & + & + & + & + & + \\
\hline
\end{tabular}


Table 3 Regression analyses of elemental concentrations in individual cell types (to interpret abbreviations used below for plant and cell names, refer to Table 1)

\begin{tabular}{|c|c|c|c|c|c|c|c|c|c|c|c|}
\hline Plant & Cell & Elements & $\mathbf{R}$ & $r^{2}$ & $P$ & Plant & Cell & Elements & $\mathbf{R}$ & $r^{2}$ & $P$ \\
\hline \multirow{6}{*}{$V n$} & pal 1\&2 & $\mathrm{Mn} / \mathrm{Mg}$ & -0.06 & 0.00 & 0.87 & $G a$ & $\mathrm{sm}$ & $\mathrm{Mn} / \mathrm{Mg}$ & 0.37 & 0.13 & 0.13 \\
\hline & & $\mathrm{Mn} / \mathrm{P}$ & 0.04 & 0.00 & 0.90 & & & $\mathrm{Mn} / \mathrm{P}$ & 0.17 & 0.03 & 0.51 \\
\hline & & $\mathrm{Mn} / \mathrm{S}$ & 0.89 & 0.78 & 0.00 & & & $\mathrm{Mn} / \mathrm{S}$ & 0.30 & 0.09 & 0.22 \\
\hline & & $\mathrm{Mn} / \mathrm{Cl}$ & 0.01 & 0.00 & 1.00 & & & $\mathrm{Mn} / \mathrm{Cl}$ & -0.25 & 0.06 & 0.31 \\
\hline & & $\mathrm{Mn} / \mathrm{K}$ & -0.18 & 0.03 & 0.62 & & & $\mathrm{Mn} / \mathrm{K}$ & -0.62 & 0.39 & 0.01 \\
\hline & & $\mathrm{Mn} / \mathrm{Ca}$ & -0.39 & 0.15 & 0.27 & & & $\mathrm{Mn} / \mathrm{Ca}$ & 0.16 & 0.03 & 0.52 \\
\hline \multirow[t]{6}{*}{$G a$} & ue 1 & $\mathrm{Mn} / \mathrm{Mg}$ & -0.94 & 0.88 & 0.06 & & le & $\mathrm{Mn} / \mathrm{Mg}$ & 0.44 & 0.19 & 0.56 \\
\hline & & $\mathrm{Mn} / \mathrm{P}$ & 0.01 & 0.00 & 0.99 & & & $\mathrm{Mn} / \mathrm{P}$ & -0.67 & 0.45 & 0.33 \\
\hline & & $\mathrm{Mn} / \mathrm{S}$ & -0.95 & 0.91 & 0.05 & & & $\mathrm{Mn} / \mathrm{S}$ & 0.32 & 0.11 & 0.68 \\
\hline & & $\mathrm{Mn} / \mathrm{Cl}$ & -0.91 & 0.84 & 0.09 & & & $\mathrm{Mn} / \mathrm{Cl}$ & 0.66 & 0.44 & 0.34 \\
\hline & & $\mathrm{Mn} / \mathrm{K}$ & -0.93 & 0.87 & 0.07 & & & $\mathrm{Mn} / \mathrm{K}$ & 0.93 & 0.87 & 0.07 \\
\hline & & $\mathrm{Mn} / \mathrm{Ca}$ & 0.97 & 0.94 & 0.03 & & & $\mathrm{Mn} / \mathrm{Ca}$ & 0.12 & 0.01 & 0.88 \\
\hline \multirow{6}{*}{\multicolumn{2}{|c|}{ ue 2}} & $\mathrm{Mn} / \mathrm{Mg}$ & 0.44 & 0.19 & 0.46 & $M f$ & hypo 1 & $\mathrm{Mn} / \mathrm{Mg}$ & 0.56 & 0.31 & 0.09 \\
\hline & & $\mathrm{Mn} / \mathrm{P}$ & 0.76 & 0.57 & 0.14 & & & $\mathrm{Mn} / \mathrm{P}$ & -0.10 & 0.01 & 0.63 \\
\hline & & $\mathrm{Mn} / \mathrm{S}$ & -0.53 & 0.28 & 0.36 & & & $\mathrm{Mn} / \mathrm{S}$ & 0.47 & 0.22 & 0.17 \\
\hline & & $\mathrm{Mn} / \mathrm{Cl}$ & -0.74 & 0.55 & 0.15 & & & $\mathrm{Mn} / \mathrm{Cl}$ & -0.15 & 0.02 & 0.67 \\
\hline & & $\mathrm{Mn} / \mathrm{K}$ & -0.44 & 0.19 & 0.46 & & & $\mathrm{Mn} / \mathrm{K}$ & -0.17 & 0.03 & 0.64 \\
\hline & & $\mathrm{Mn} / \mathrm{Ca}$ & 0.67 & 0.45 & 0.21 & & & $\mathrm{Mn} / \mathrm{Ca}$ & 0.55 & 0.3 & 0.1 \\
\hline \multirow{6}{*}{\multicolumn{2}{|c|}{ se }} & $\mathrm{Mn} / \mathrm{Mg}$ & 0.07 & 0.01 & $0.91^{\circ}$ & & hypo 2 & $\mathrm{Mn} / \mathrm{Mg}$ & -0.27 & 0.07 & 0.46 \\
\hline & & $\mathrm{Mn} / \mathrm{P}$ & -0.16 & 0.03 & 0.80 & & & $\mathrm{Mn} / \mathrm{P}$ & 0.08 & 0.01 & 0.82 \\
\hline & & $\mathrm{Mn} / \mathrm{S}$ & 0.79 & 0.63 & 0.11 & & & $\mathrm{Mn} / \mathrm{S}$ & 0.25 & 0.06 & 0.49 \\
\hline & & $\mathrm{Mn} / \mathrm{Cl}$ & -0.86 & 0.73 & 0.07 & & & $\mathrm{Mn} / \mathrm{Cl}$ & -0.21 & 0.04 & 0.57 \\
\hline & & $\mathrm{Mn} / \mathrm{K}$ & -0.66 & 0.43 & 0.23 & & & $\mathrm{Mn} / \mathrm{K}$ & -0.63 & 0.40 & 0.05 \\
\hline & & $\mathrm{Mn} / \mathrm{Ca}$ & 0.94 & 0.89 & 0.02 & & & $\mathrm{Mn} / \mathrm{Ca}$ & 0.28 & 0.08 & 0.43 \\
\hline \multirow{6}{*}{\multicolumn{2}{|c|}{ pal 1}} & $\mathrm{Mn} / \mathrm{Mg}$ & 0.51 & 0.26 & 0.16 & & lie. & $\mathrm{Mn} / \mathrm{Mg}$ & -0.13 & 0.02 & 0.73 \\
\hline & & $\mathrm{Mn} / \mathrm{P}$ & -0.21 & 0.04 & 0.56 & & & $\mathrm{Mn} / \mathrm{P}$ & 0.45 & 0.21 & 0.19 \\
\hline & & $\mathrm{Mn} / \mathrm{S}$ & 0.49 & 0.24 & 0.15 & & & $\mathrm{Mn} / \mathrm{S}$ & 0.26 & 0.07 & 0.47 \\
\hline & & $\mathrm{Mn} / \mathrm{Cl}$ & -0.42 & 0.18 & 0.22 & & & $\mathrm{Mn} / \mathrm{Cl}$ & 0.40 & 0.16 & 0.25 \\
\hline & & $\mathrm{Mn} / \mathrm{K}$ & -0.32 & 0.10 & 0.36 & & & $\mathrm{Mn} / \mathrm{K}$ & -0.41 & 0.17 & 0.24 \\
\hline & & $\mathrm{Mn} / \mathrm{Ca}$ & -0.18 & 0.03 & 0.62 & & & $\mathrm{Mn} / \mathrm{Ca}$ & -0.18 & 0.03 & 0.63 \\
\hline \multirow{6}{*}{\multicolumn{2}{|c|}{ pal 2}} & $\mathrm{Mn} / \mathrm{Mg}$ & 0.76 & 0.58 & 0.01 & & & & & & \\
\hline & & $\mathrm{Mn} / \mathrm{P}$ & -0.01 & 0.00 & 0.97 & & & & & & \\
\hline & & $\mathrm{Mn} / \mathrm{S}$ & 0.26 & 0.07 & 0.47 & & & & & & \\
\hline & & $\mathrm{Mn} / \mathrm{Cl}$ & 0.39 & 0.15 & 0.27 & & & & & & \\
\hline & & $\mathrm{Mn} / \mathrm{K}$ & 0.90 & 0.80 & 0.00 & & & & & & \\
\hline & & $\mathrm{Mn} / \mathrm{Ca}$ & 0.20 & 0.04 & 0.58 & & & & & & \\
\hline
\end{tabular}

Fig. 1 Secondary electron image and corresponding $\mathrm{Mn}, \mathrm{K}, \mathrm{Ca}, \mathrm{Mg}, \mathrm{Cl}, \mathrm{S}$ and $\mathrm{P} \mathrm{X}$-ray maps of a frozen leaf- cross-sectional surface of $V$. neurophylla. Bright areas within X-ray maps indicate elemental distribution, i.e. the greater the concentration, the brighter the signal. Degrees of brightness cannot be used to compare relative concentrations between elements. Adaxial surface at LHS. 
Fig. 2 Secondary electron image and corresponding $\mathrm{Mn}, \mathrm{K}, \mathrm{Ca}, \mathrm{Mg}, \mathrm{Cl}, \mathrm{S}$ and $\mathrm{P} \mathrm{X}$-ray maps of a frozen leaf- cross-sectional surface of M. fournieri. Bright areas within X-ray maps indicate elemental distribution, i.e. the greater the concentration, the brighter the signal. Degrees of brightness cannot be used to compare relative concentrations between elements. Adaxial surface at LHS.

Fig. 3 Secondary electron image and corresponding $\mathrm{Mn}, \mathrm{K}, \mathrm{Ca}, \mathrm{Mg}, \mathrm{Cl}, \mathrm{S}$ and $\mathrm{P} \mathrm{X}$-ray maps of a frozen leaf- cross-sectional surface of G. amplexicaulis. Bright areas within X-ray maps indicate elemental distribution, i.e. the greater the concentration, the brighter the signal. Degrees of brightness cannot be used to compare relative concentrations between elements. Adaxial surface at RHS.

Fig. 4 Detailed SEI images and in vivo Mn X-ray maps of Mn sinks in frozen leaf crosssectional surfaces of a) V. neurophylla, and b) M. fournieri. The thermal colour scale represents highest to lowest concentrations from white to blue. Yellow areas here correspond to highest Mn deposition; however degrees of brightness cannot be used to compare relative concentrations between maps. Chloroplasts are arrowed in a), adaxial surfaces at LHS. 


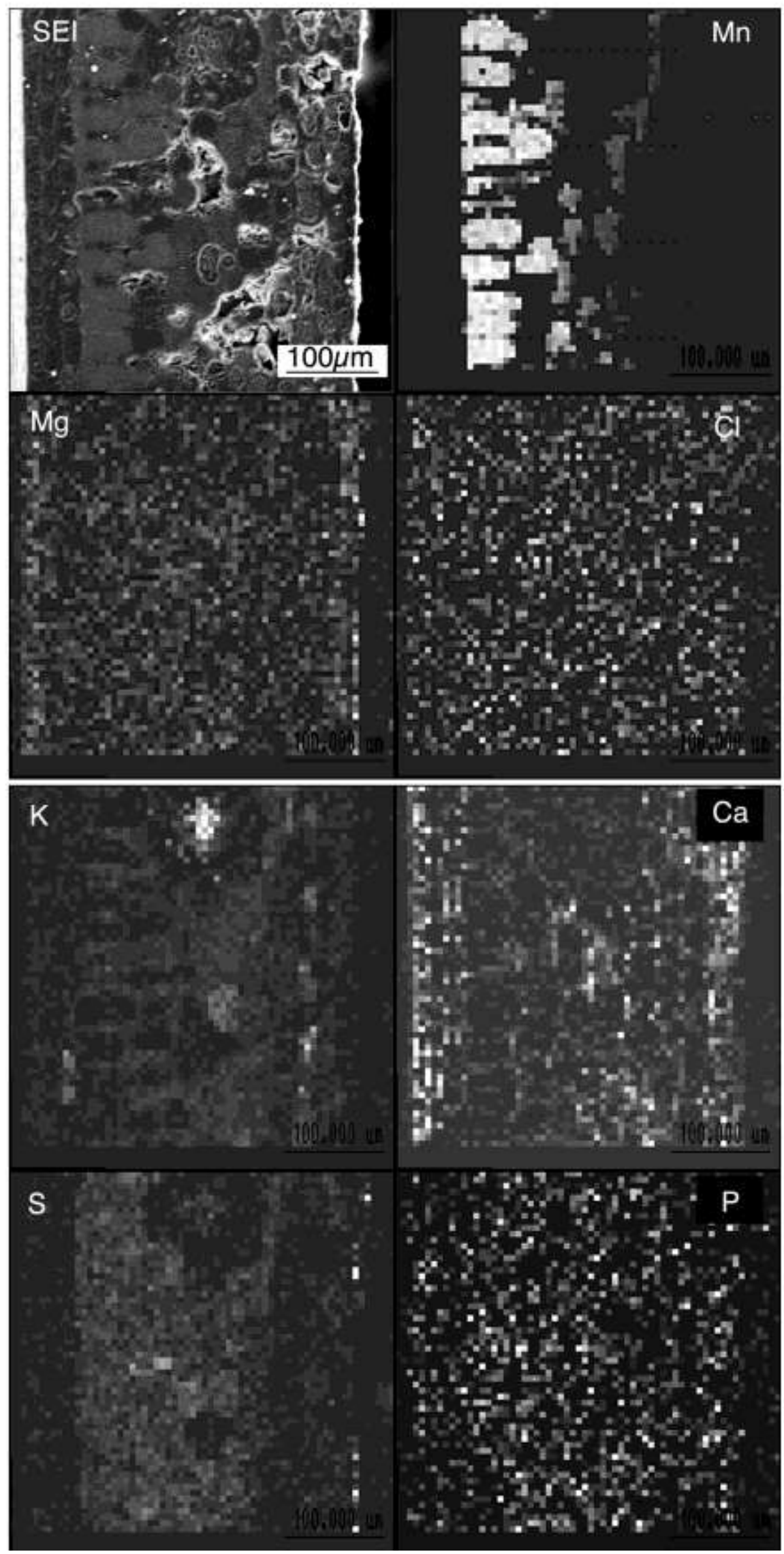




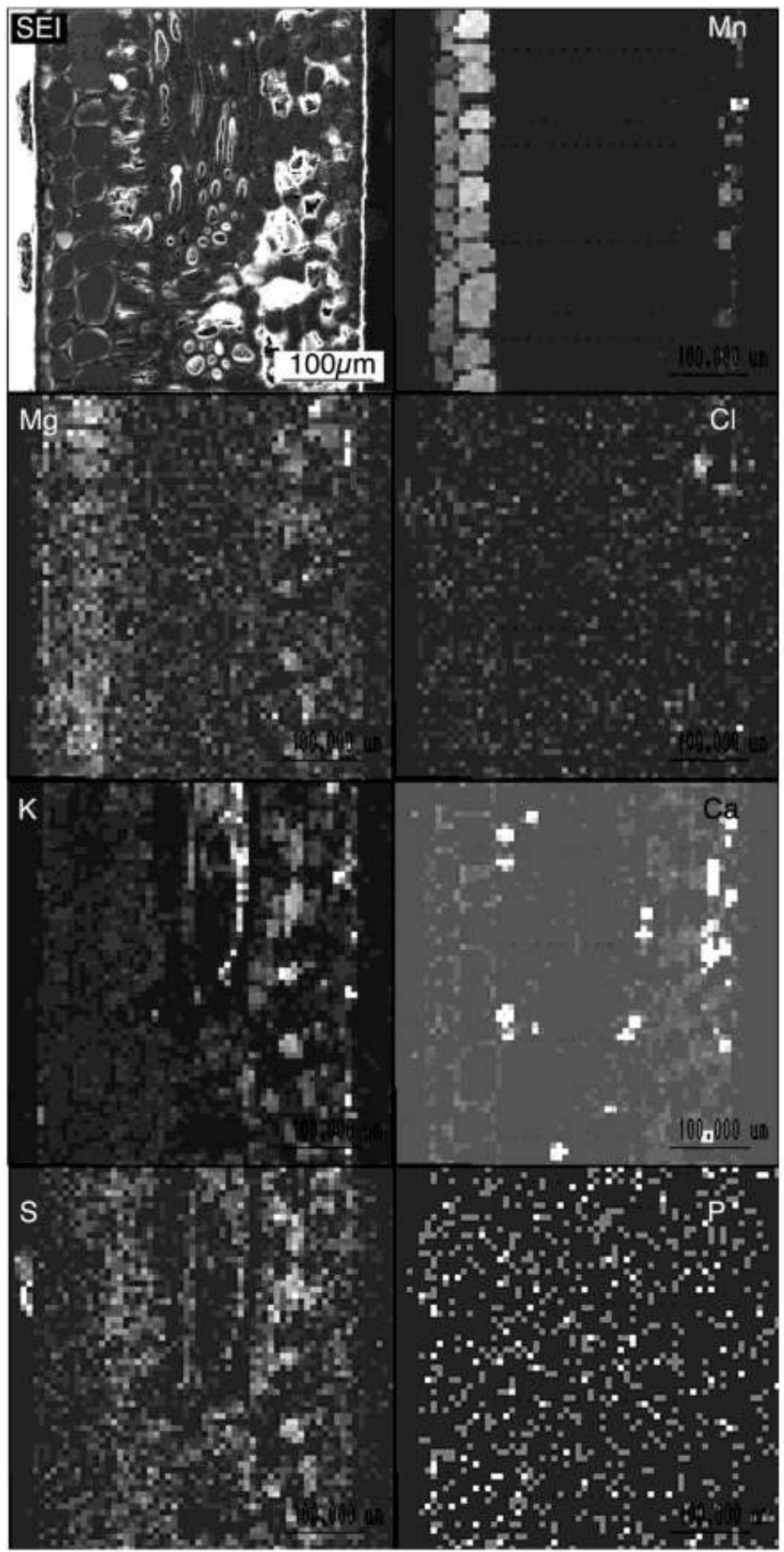




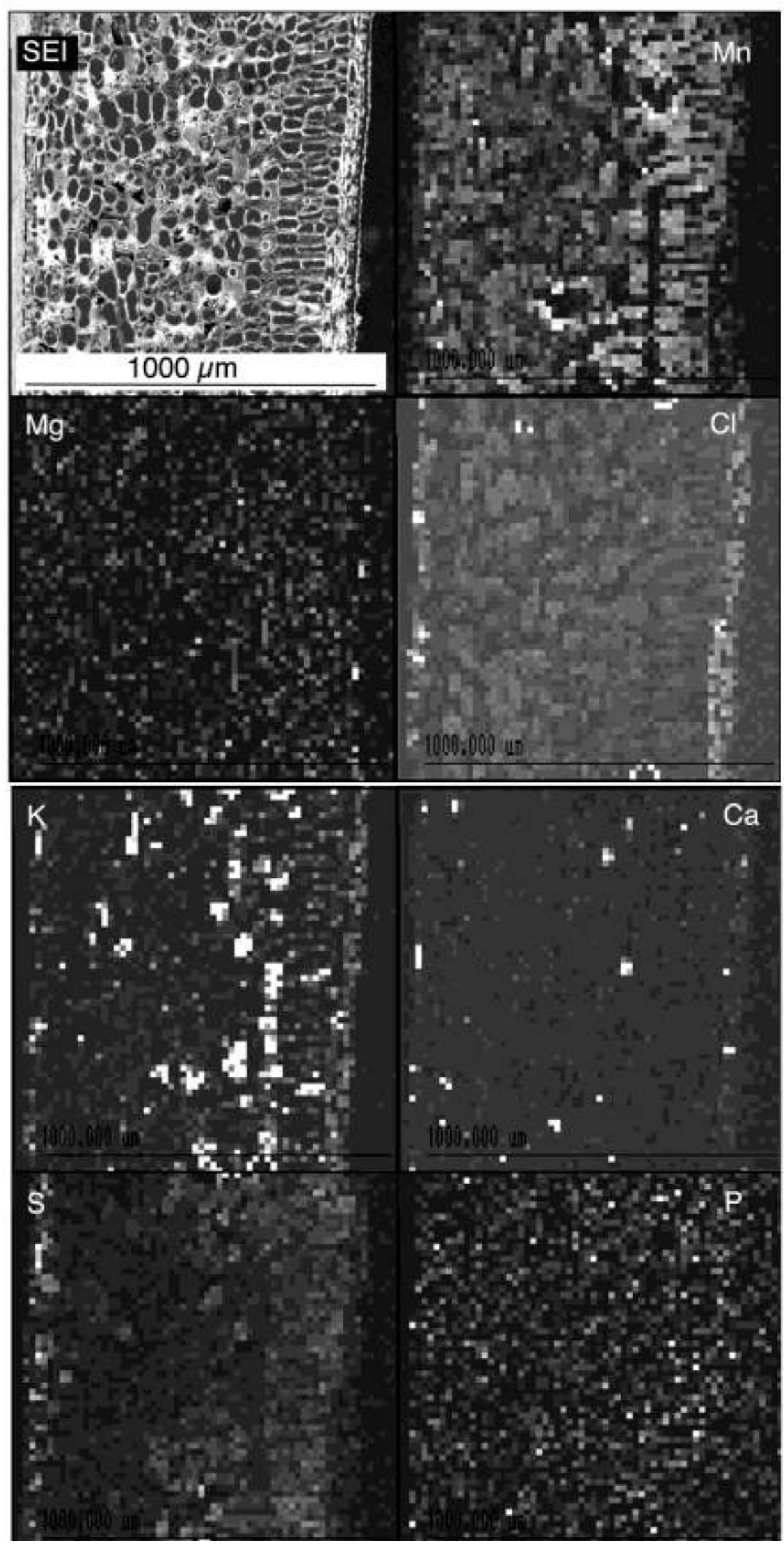



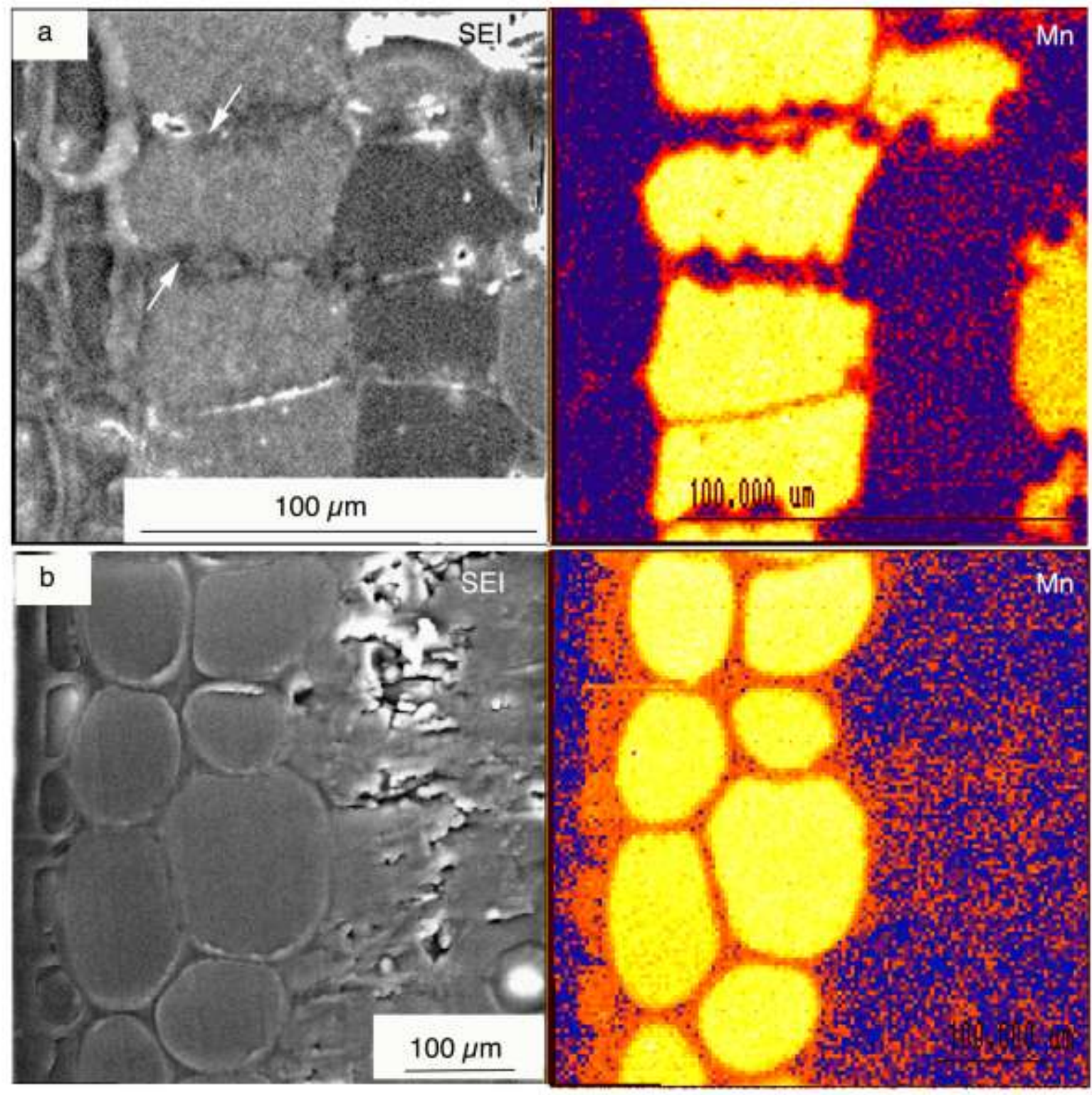


\section{University Library}

\section{- M M N E R VA A gateway to Melbourne's research publications}

Minerva Access is the Institutional Repository of The University of Melbourne

Author/s:

Fernando, DR;Woodrow, IE;Baker, AJM;Marshall, AT

Title:

Plant homeostasis of foliar manganese sinks: specific variation in hyperaccumulators

Date:

2012-11-01

Citation:

Fernando, D. R., Woodrow, I. E., Baker, A. J. M. \& Marshall, A. T. (2012). Plant homeostasis of foliar manganese sinks: specific variation in hyperaccumulators. PLANTA, 236 (5), pp.1459-1470. https://doi.org/10.1007/s00425-012-1699-6.

Persistent Link:

http://hdl.handle.net/11343/282799 